\title{
Joint Forest Management in Katanino, Zambia: Inappropriate Property Regime Change?
}

\author{
Bridget Bwalya Umar ${ }^{*}, 1,2$ and Paul Vedeld ${ }^{2}$ \\ ${ }^{I}$ Geography and Environmental Studies Department, School of Natural Sciences, University of Zambia, P.O. Box 32379, \\ Lusaka 10101, Zambia \\ ${ }^{2}$ Department of International Environment and Development Studies, Norwegian University of Life Sciences, Box 5003, \\ N-1432 Aas, Norway
}

\begin{abstract}
This research study reports on a Joint Forest Management (JFM) program in Katanino Area, Zambia. Data was collected through a questionnaire survey, unstructured group interviews, focus group discussions, key informant interviews, and field observations. Results show that forest resources from Katanino Forest contributed only $3 \%$ to the total household incomes while $40 \%$ of respondents reported not obtaining any forest resources from Katanino Forest. Only 12 residents were involved in JFM activities while $60 \%$ of the respondents reported never having attended a meeting where JFM issues were discussed. Despite the weak institutional framework, we found the Katanino Forest to be in a good physical condition. This most likely reflects a situation of low rivalry in terms of consumption and medium costs of exclusion; normally not a situation where a rather costly common property regime would be a fitting institution. The good condition of the forest could be seen as an indication of the success, to some extent, of the previous property regime and the redundancy of a property regime change at the time, especially for an area where the local communities had alternative sources of forest resources. A main lesson to be learnt is to avoid costly and inappropriate property regime changes. One should design JFM policies to involve various actors, social institutions, and local organizations from the start; to provide and develop local ownership; and to take appropriate consideration of local resource conditions and social heterogeneity.
\end{abstract}

Keywords: Elite capture, institutions, joint forest management, Katanino, livelihoods, participation.

\section{INTRODUCTION}

Conservation policies involving local people in natural resource management have dominated the development field after the "fortress conservation" narrative lost ground [1]. However, emerging experiences are mixed, with increasing calls for going "back to the barriers" [2]. The colonial administration in Zambia created 'fortresses' by designating protected areas such as national parks and gazetted forests. After independence the Zambian government continued these exclusionary policies which were consciously maintained because politicians could use the resources in protected areas for patronage in political processes [3].

Approximately 66\% (49.9 million ha) of Zambia's land area is covered by forests [4]. The forestry sector contributed about $4 \%$ to Zambia's GDP in $2004[5,6]$ and employed about 1.1 million Zambians [7]. About 9\% of the forests are protected areas, managed by the Forestry Department (FD). In the late 1990s, the Zambian government reviewed its forestry policies and legislation, resulting in the Forest Policy of 1998 and the Forest Act of 1999. Statutory Instrument No. 52 of 1999 provided a legal basis for piloting the novel Joint Forest Management (JFM) program that

Address correspondence to this author at the Geography and Environmental Studies Department, School of Natural Sciences, University of Zambia, P.O. Box 32379, Lusaka 10101, Zambia; Tel: 260211 290603; +260 211 293365; E-mail: brigt2001@yahoo.co.uk commenced in 2000. The objective was to bring de facto open access forests under formal community management. A key objective of this study therefore, was to document the experiences of JFM implementation using Katanino Forest as a case study. We assess the effectiveness of the JFM institutions in the Katanino Forest area and the appropriateness of the property regime change. We also offer some recommendations for improved JFM policy implementation.

\section{THEORY AND LITERATURE REVIEW}

The old conventional wisdom in commons management was that users of commons were not able to organize and avoid over-harvesting by themselves, and that the solution was the institution of private property coupled with legal inheritance [8]. A lack of well-defined and secure property rights was seen to be one important reason for the massive degradation of natural resources in developing countries [9]. It was claimed that forest-dependent people were the main agents responsible for forest degradation and deforestation, as poorly articulated and enforced property rights arrangements provided disincentives for individuals to protect resources [10]. An exclusionary, state-controlled, top-down forest management approach was seen as being required to achieve sustainable forest management [11]. This view was based on the assumption that a government is capable of enforcing its property rights over forests. 
In many cases, the devotion to a centrally designed, scientifically informed forest policy meant in reality that many forests have been under open access regimes and have become degraded over time. Apart from de facto user rights, local users do not have rights to govern the use of forests and forest resources [12]. To address these problems, community based forest management, in its various manifestations, is being increasingly promoted. It has been argued that the participation of local communities can bring about more sustainable and equitable forms of natural resource management [13, 14]. Extensive empirical research has shown that local forest users typically impose rules and regulations for harvesting regimes that often secure sustainable forest management [15]. Selforganization is more likely to occur when forest resources are highly salient to users; when users have a common understanding of the problems they face; they trust one another, have autonomy to make some of their own rules, and have prior organizational experience [16].

While the details of JFM vary considerably from place to place, a common characteristic is that local communities often receive somewhat greater property rights, responsibilities and influence over local natural resources than they had under preceding regimes [16]. Property regimes move from the de facto open access under state management to variants of common property under JFM. The main strategy of such co-management schemes is to provide local communities with feasible economic alternatives that help to reduce their dependence on natural resources in protected areas [17].

\subsection{Resource Attributes, Rights, and Resource Regimes}

\subsubsection{Resource Attributes}

The physical attributes of a resource have implications for its management. Common Pool Resources (CPRs) are characterized by two physical attributes: rivalry in consumption and the difficulty of exclusion (excludability). Rivalry in consumption implies that when someone uses a good, others cannot use it as well. CPRs are threatened by overuse leading to congestion or destruction of the resource [18-20]. Excludability is important because commons management is more likely to work if the users enjoy exclusive rights to the resource and have a stake in conserving it [21]. Successful commons management is only likely to happen if rivalry in consumption provides incentives for users to exclude others.

\subsubsection{Rights}

Rights refer to particular authorized actions, while rules are generally agreed upon and enforced prescriptions that require, forbid, or permit specific actions for more than a single individual $[22,23]$. A property right is the authority to undertake particular actions related to a specific domain [24]. Within a single CPR situation, a conglomeration of de jure and de facto property rights may exist, that overlap, complement, or even conflict with one another [25]. Different bundles of property rights, whether de facto or de jure, affect the incentives individuals enjoy, the types of actions they take, and the outcomes they achieve. Five property rights that are most relevant for the management of CPRs are identified in Table 1 [26].

\subsubsection{Resource Regimes}

Resource regimes are institutional structures governing resource use through regulating access to resources, and rules concerning the interaction between actors. They consist of (a) the property regime governing the use and transfer of the resource itself (property right), and (b) the rules and norms that govern the transactions concerning the products made from the resource (product transfer). Regimes may influence the use of CPRs through both their sanctioning systems and their effect on how easy and meaningful it is to for the various actors to cooperate with each other [27]. A framework for analyzing resource use problems is presented below (Fig. 1).

\section{Table 1. Different Types of Rights to Property}

\begin{tabular}{|l|l|}
\hline \multicolumn{1}{|c|}{ Property } & \multicolumn{1}{c|}{ Description } \\
\hline \hline Access: & $\begin{array}{l}\text { The right to enter a defined physical area and enjoy } \\
\text { non-subtractive benefits (e.g. hiking). }\end{array}$ \\
\hline Withdrawal: & $\begin{array}{l}\text { The right to obtain resource units or products of a } \\
\text { resource system( e.g. mushroom picking). }\end{array}$ \\
\hline Management: & $\begin{array}{l}\text { The right to regulate internal use patterns and } \\
\text { transform the resource by making improvements. }\end{array}$ \\
\hline Exclusion: & $\begin{array}{l}\text { The right to determine who will have an access right, } \\
\text { and how that right may be transferred. }\end{array}$ \\
\hline Alienation: & $\begin{array}{l}\text { The right to sell or lease either or both of the above } \\
\text { collective-choice rights }\end{array}$ \\
\hline Source: [26]. & \multicolumn{2}{l}{} \\
\hline
\end{tabular}

According to this model, resource use and resource status depend on four factors:

(I) Attributes of the resource and the technology available for its utilization: These characteristics influence whether or not a coordination problem exists. If the resource is vast compared to the capacity people have to utilize it, there may be no need to regulate access. Such a situation is characterized by non-rivalry. Resource characteristics influence outcomes both directly (a) and via the way they influence agents' choices $\left(b_{1}\right.$ and $\left.b_{2}\right)$.

(II) The institutions or regimes consist of conventions, norms and formal rules. Some regimes may lack a system involving third party control, implying that regulations are built into the conventions and norms of the regime. A core issue is how the regime fits the characteristics of the resource and the technology involved.

(III) Agents and agent choices: Institutional structures, opportunities provided by technology and the characteristics of the resource heavily influence agents' choices. A system may fit the dynamics of the resource well, but may still be undermined if the agents involved are motivated to break the rules.

(IV) Problems appear as a consequence of the interaction of choices made by several agents. Typically, given resource characteristics, technology, and the number of agents, the regime may be unable to motivate coordinated action in accordance with what is demanded [27]. 
(I)

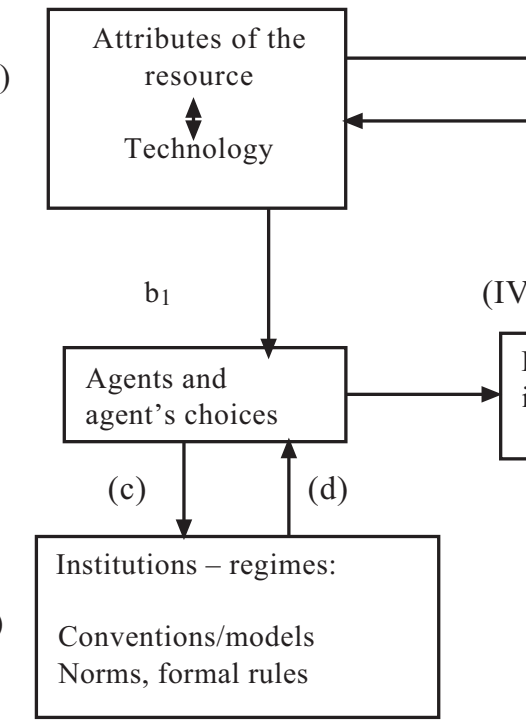
(IV)

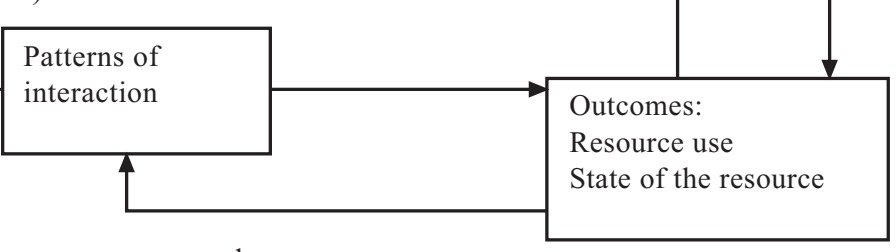

$\mathrm{b}_{2}$

Fig. (1). Framework for Analysing Resource Use Problems (Source: [27]).

\section{JOINT FOREST MANAGEMENT IN ZAMBIA}

Joint Forest Management (JFM) in Zambia is organized vertically according to central, district, area and village levels (Fig. 2). The Environmental and Natural Resources Sub-Committee of the District Development Coordinating Committee coordinates all natural resource management issues at district level including JFM activities. At the JFM area level the Forest Management Committee (FMC) has substantial representation from the state and some representation from local levels. At the village level there is the Village Resource Management Committee (VRMC) with a representative on the FMC [28, 29]. The Katanino community thus formally participates in JFM decisionmaking processes through representation on the VRMCs and the FMC.

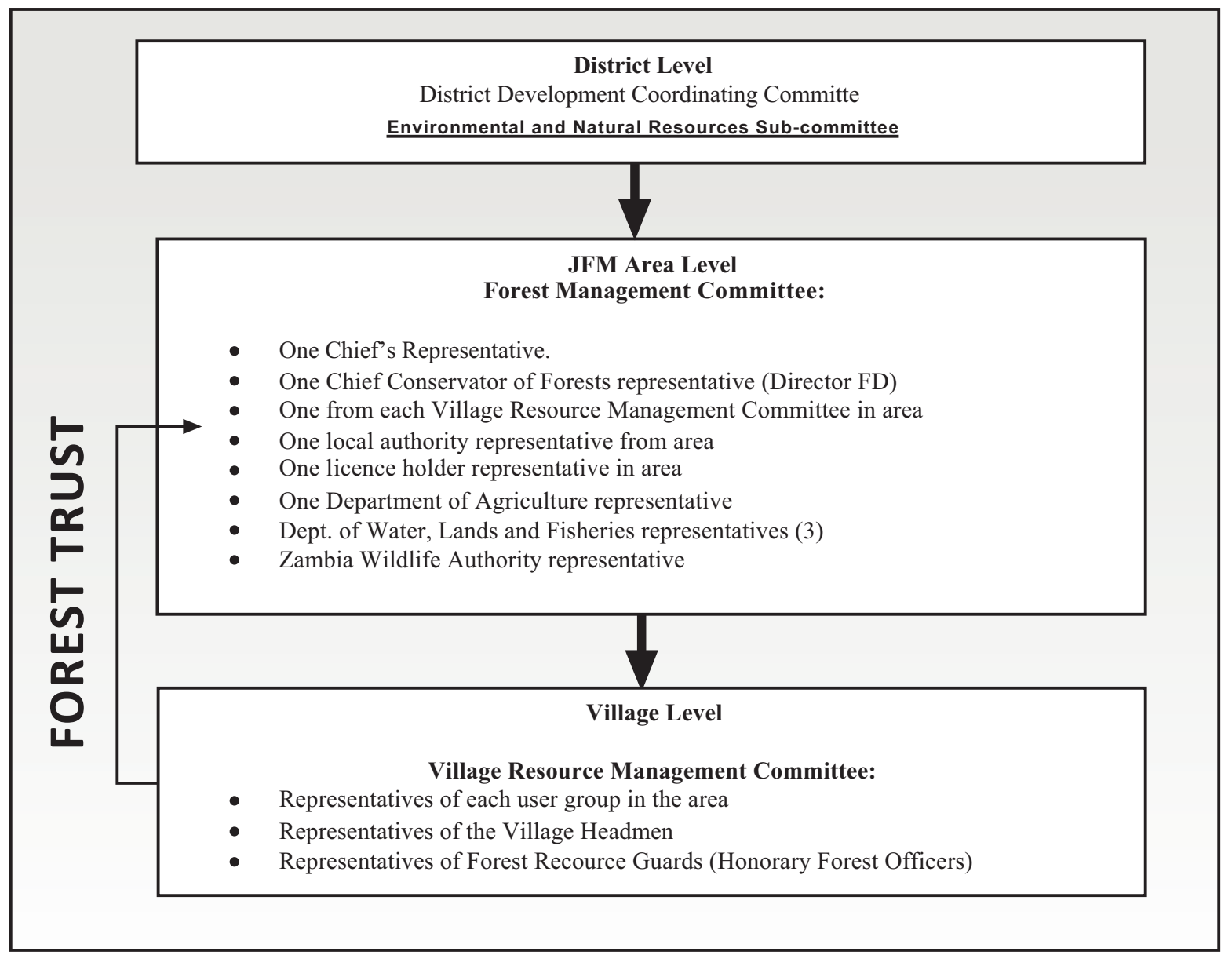

Fig. (2). Joint Forest management structure in Zambia. 
It has been argued that a major reason behind the transition to JFM was the state's need to reduce forest management costs by delegating work to the local communities [30], and not necessarily to give more rights to communities [31,32]. An important question is then how far central government will go in devolving powers, resources and authority; and the appropriateness of the resulting property regimes in local contexts. The prescribed composition of JFM committees in the Forest Act does not cater for handling dynamic complexities at community levels [33]; nor does the Act specify explicit roles for chiefs and their local institutions. This is clearly an aberration, considering the authority commanded by chiefs in Zambia's traditional society $[30,33]$. The benefits that local communities may derive from jointly managed forests are mainly revenues from forest permits, which are shared with the central government [34].

\section{DESCRIPTION OF STUDY AREA AND DATA COLLECTION METHODS}

\subsection{Description of Study Area}

The Katanino Local Forest is situated southeast of Masaiti District, about $80 \mathrm{~km}$ from Ndola on the NdolaKapiri Road (Fig. 3). Its area of 4532 hectares shares boundaries with four amalgamated JFM villages, namely Oposhi, Bwengo, Serenje and Biwa. For purposes of JFM, the villages surrounding the Katanino Forest were combined to form the four 'villages' referred to in the Katanino JFM Plan and in this study. This was done to simplify management by having a smaller number of local committees and village representatives. In reality, each JFM village consists of around 20-30 actual villages, each being typically made up of a group of extended family or clan members consisting of about 10 households [35].

The area receives rainfall between November and April (annual average of 1000-1400 mm) while the months from May to September are completely dry. Temperature ranges from 16 to $27^{\circ} \mathrm{C}$ in the cool and dry season, and from $27^{\circ} \mathrm{C}$ to $38^{\circ} \mathrm{C}$ in the hot and wet season [7].

There were 3842 households registered in the Katanino JFM Area in 2003, with an average of 5 members per household [35]. Subsistence agriculture is the main source of livelihood and hand hoes are the dominant means of production. Livestock includes sheep, goats, pigs, ducks, chickens, pigeon, geese and cattle. Livestock is of marginal importance with less than $1 \mathrm{TLU}^{1}$ per household, and cattle are not traditionally reared in the area. There is a trend towards keeping animals like goats and chicken as they are perceived to be less vulnerable to drought and are easier to manage and sell. The main crops grown are maize (Zea mays L), sweet potatoes (Ipomea batatas L), cassava (Manihot esculenta Crantz), sorghum (Sorghum bicolour L), groundnuts (Arachis hypogaea L), and vegetables. The average land size per household is 5-10 hectares; thus land is quite abundant.

\footnotetext{
${ }^{1}$ A Total Livestock Unit (TLU) is a summation of livestock units. A Livestock Unit is a unit that represents an animal of $250 \mathrm{~kg}$ live weight and is used to aggregate different species and classes of livestock as follows; cattle: 0.5 ; goat and sheep: 0.1 ; pig: 0.2 ; chicken and other poultry: 0.02 .
}

In 2003, national rural poverty levels were reported to be at $83 \%$ while the Copperbelt province had overall poverty levels of $65 \%$ [37]. Similar to other rural areas, poverty is widespread in the study area. The Katanino JFM Area is traversed by the Ndola-Kapiri Road, the main highway from the highly urbanized Copperbelt Province to Lusaka, the national capital. The road is a link to markets for crops and forest products, and facilitates transport of produce to Lusaka. The nearby government maize depot enables easy market access for local farmers. The good rainfall and agricultural soils, combined with the central government's agricultural subsidy programme providing farmers with mineral fertilizers and maize seed at $50 \%$ of the market price, result in high production levels.

The Katanino villages are inhabited by more than 13 different tribal groupings such as the Lala, Lamba, Bemba, Kaonde, Shona, Luvale, Tumbuka, Namwanga, Lenje, Swaka, Tonga, Nsenga, and Yao. This reflects the heterogeneity and historical in-migration of pensioners and retrenchees from nearby mining towns, and farmers from the drought prone Southern Province, who settled in the area. The settlers from mining towns were usually more cash oriented, better educated, and of higher socio-economic status than other community members. Being a close relative of either a chief or founder of a very old village also conferred higher social standing on an individual.

A chief, with sub-chiefs and headmen under him, heads a chiefdom. A sub-chief is in charge of up to 10 villages, while a headman is in charge of a single village. In Zambia, chiefs command a lot of respect and are symbols of power and authority. They are not elected but assume office through succession. Chiefs are the custodians of all land in their chiefdoms, except that gazetted or set aside as protected. This means that any person wanting to settle in their chiefdom has to seek their permission and apply for land from them for use either to set up a homestead or for agriculture. The chief also acts as an arbitrator in both civil and criminal cases brought to him involving his subjects. The chief determines land use, access and user rights on customary land in accordance with the traditional practices of a particular tribal grouping, while the Forestry Department determines the utilization and management of the forest resource on that land. However, most communities in customary areas perceive the chiefs as the owners and controllers of all the land and the natural resources on it, despite the law stating that land is vested in the president under the Lands Act of 1995 [33]. The Katanino area is under the traditional authority of three chiefs (Chiefs Mushili, Nkambo and Chieftainess Malembeka).

Katanino Forest vegetation types are typical of the Copperbelt Province and are characterized by $90 \%$ single storey, deciduous and closed canopy woodland known as Miombo Woodland [36]. Species found include Julbernadia paniculata Benth., Marquesia macroura Gilg, Brachystegia longiflora Benth., Brachystegia utilis Burtt Davyand Hutch, Brachystegia boehmii Taub, Isoberlinia angolensis Welw. Ex. Benth, Uapaca kirkiana Muell.Arg, Anisophellia sp.pl., Parinari curatellifolia Planch. Ex. Benth, Albizia adiantifolia, Schumach, Albizia versicolor Welw. ex. Oliv, and Oxytenanthera abyssinica A. Rich. Large termitaria (up to 5 meters or more in height) are found almost throughout 


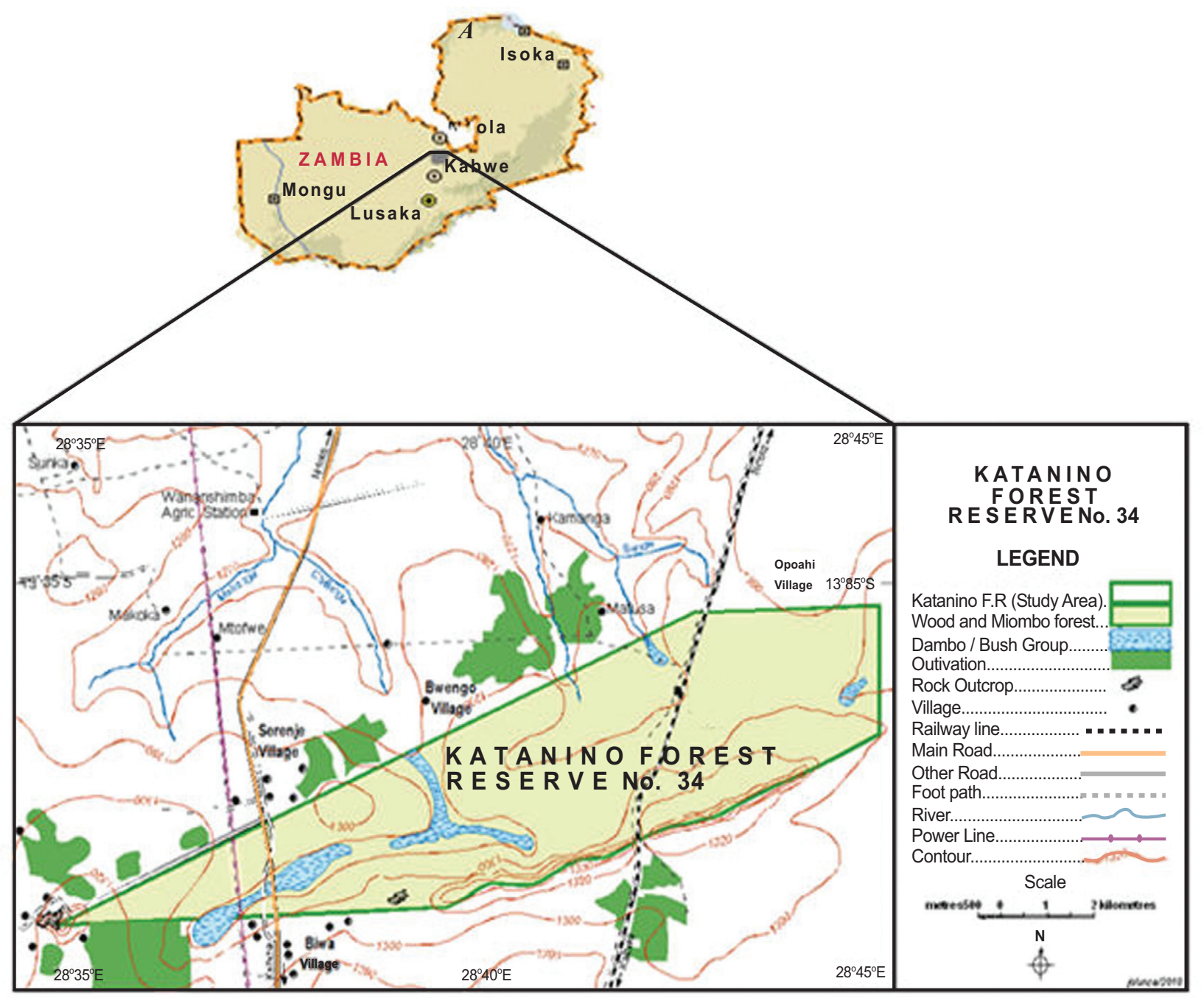

Fig. (3). Katanino Forest Reserve No. 34 and Map sheet 1328 D1, updated from Google Image 2010.

the forest. The termitaria support distinct vegetation types, among which are Cassia abbreviate Oliv., Combretum sp.pl., Ficus sp.pl. and Erithrina sp.pl.. Valuable timber species are not abundant but there is a good stock of mine quality timber. Fires remain a major threat to the normal growth of the forest. The topography is generally undulating with few hill formations, the most prominent of which are the Katanino Hills. Leached sand veldt soils, which are light sandy loams or loamy sands with inert clay and low base saturation (due to leaching by excessive rainfall), are found in a wide area of the forest [36].

\subsection{Data Collection}

The study was carried out from November 2006 to February 2007. We used both quantitative and qualitative research methods. Data collection comprised field transects and questionnaire surveys $(\mathrm{N}=75)$, complemented by individual and group interviews, focus group discussions, key informant interviews, observations, and informal discussions with residents and stakeholders of the study area [35].
The JFM Area community was operationalized as residents living within a range of $5 \mathrm{~km}$ from the Katanino Forest [33]. The two JFM villages (Biwa and Serenje) were purposively sampled and questionnaires administered to households living there. These two JFM villages were assumed to be good representatives of all the JFM villages as there are no systematic differences between them, and, as already explained, their categorization into JFM villages was done arbitrarily. The households were randomly selected from the village registers. Heads of households were targeted as respondents. In the few instances that they were not available, their spouses were interviewed. Mostly, male household heads were aided by their wives in answering questions. The questionnaires included questions on household income sources, use and sources of forest resources, knowledge of Katanino JFM, its institutions and their performance, participation in JFM activities etc. Two focus group discussions were conducted. Discussants were members of local JFM institutions (VRMC, FMC, user groups) and ordinary community members.

Two transect walks were conducted with six children (male, aged between 10-16 years) and two adults (male and female) from the same two villages where questionnaires had 
been administered. The children detailed the types of resources they collected from different areas of the forest at different times. The adults explained the uses of the different forest resources by adult community members and pointed out the areas from where the various resources were usually appropriated. During the transect walks, observations were made on the general state of the forest, e.g. whether trees had been felled for charcoal production, harvesting of beehives, caterpillars, or bark rope. The physical condition of the forest was further observed during the survey as the forest was criss-crossed on numerous occasions during the survey. Informal discussions were conducted with other residents through such activities as participation in ordinary activities e.g. sharing meals, drawing water from the river, attending village meetings. Key informants included two headmen, a volunteer from the American Peace Corps who had worked on JFM in the area for over a year, officials from the district office of the FD, and an official from the FD headquarters in Lusaka.

\subsection{Data Analysis}

Statistical analyses were carried out using MINITAB 14 [38]. The questionnaire survey data were analyzed using a two-sample T-test and Analysis of Variance (ANOVA) at a significance level of $p \leq 0.05$. Descriptive statistics such as means, standard deviations and percentages were also used to analyze results from the questionnaire survey and field assessments. The Framework for Analyzing Resource Use Problems [27] was used for reflecting on the resource regimes in the study area.

\section{RESULTS AND DISCUSSION}

We present a brief livelihood analysis of the Katanino community, and link the analysis to the JFM institutions and the JFM implementation processes.

\subsection{Livelihood Analysis}

Household incomes: Farming constitutes $67 \%$ of gross annual incomes, with livestock contributing $2 \%$, and petty trade and off-farm and non-farm activities $28 \%$ (Table 2).

Table 2. Total Annual Household Income, Katanino Area

\begin{tabular}{|l|c|c|c|}
\hline \multicolumn{1}{|c|}{$\begin{array}{c}\text { Income } \\
\text { Source (ZMK) }\end{array}$} & $\begin{array}{c}\text { Mean } \\
\text { Income (ZMK) }\end{array}$ & $\begin{array}{c}\text { Share of Total } \\
\text { Income (\%) }\end{array}$ & $\begin{array}{c}\text { Standard } \\
\text { Deviation }\end{array}$ \\
\hline \hline Sweet potato & 876600 & 32.7 & 1227871 \\
\hline Maize & 796987 & 29.8 & 793717 \\
\hline Cassava & 82267 & 3.1 & 252788 \\
\hline Other crops & 41966 & 1.6 & - \\
\hline Total Crop Income & 1797820 & 67.1 & 122954 \\
\hline Livestock & 52133 & 1.9 & 1366855 \\
\hline Off and non-farm & 738267 & 27.6 & 248002 \\
\hline Total forest cash & 90533 & 3.4 & $2,028,248$ \\
\hline $\begin{array}{l}\text { Total annual } \\
\text { household income }\end{array}$ & 2678753 & 100 & \\
\hline
\end{tabular}

Most households reported selling $70-80 \%$ of their maize and sweet potatoes in order to generate cash incomes. Cash incomes were also earned from non- farm activities such as petty trade, remittances, and pensions.

Forest income dependence: Most people (60\%) reported using the Katanino Local Forest regularly for at least one type of forest product. The most common forest products harvested were wild fruits (Parinari curatellifolia, Schinzophyton rautanenii Oliv., Uapaca kirkiana, Anisophyllea boehmii Engl), mushrooms, bark rope, root tubers, leaves, caterpillars, and honey. Only $13 \%$ reported selling these products. Most of them were directly consumed by households "at the time available". Questionnaire respondents and focus group discussants complained that during the rainy season the forest products were so abundant that prices were driven down, thus making sales difficult. Such products were also found in ungazetted forests and in local residents' uncultivated or fallow lands. Only 3\% of respondents reported obtaining medicinal plants from the Katanino Local Forest, and no-one reported accessing fuel wood or fodder from the forest. This finding is similar to that from the Kilombero Nature Reserve in Tanzania, where it was reported that products that could be harvested with permits were available outside the JFM reserve and hence the arrangement of obtaining permits prior to utilization of resources from the JFM reserve remained largely unused [39].

There are no significant differences in mean cash incomes earned from forest products among the low, middle and high incomes groups $(\mathrm{p}=0.155)$. We found that forest incomes from the Katanino Local Forest constitute around $3 \%$ of total household cash incomes (Table 1). Most people in the community are crop producers with some off- and non-farm activities. Forty percent of the respondents reported not going into the Katanino Local Forest at all; they utilize forest resources, but from elsewhere. Previously reported national average percentage contribution of forest based cash incomes to total household income in Zambia is $7.3 \%$ [40]. Although we considered only forest cash incomes, they seem low compared to similar findings in other places [41], implying low environmental income dependence. Most of the environmental incomes are not from the Katanino Forest reserve but from land around people's homesteads. This has implications for the performance of the JFM scheme, which we return to later.

\subsection{Resource Attributes, Property Rights and Regimes in the Katanino JFM Area}

This section analyzes and discusses the Katanino JFM project by means of the Framework for Analysing Resource Use Problems (Fig. 1) and Schlager and Ostrom's Property Rights Relevant for the Use of CPRs [26, 27].

\subsubsection{Resource Attributes}

It is expected that communities adjacent to forests under JFM will help in forest management by policing the forest and excluding outsiders. Since community members know each other, they are likely to identify unauthorised users and prevent illegal forest exploitation. However, as articulated by [28], commons management works better if users enjoy 
exclusive rights to the resource and have a stake in conserving it. Without this incentive, the success of comanagement is less likely. We found that Katanino JFM is not working well as the users have management responsibilities which are not commensurate with the present withdrawal rights. The community members have to pay for permits that allow them to harvest non timber forest products (NTFP). There was evidence of pilfering; an indication that unauthorised forest product withdrawal is taking place, and mostly by individuals not involved in any JFM activities.

\subsubsection{Property Rights to and Regimes of the Katanino Forest}

According to Forestry Department officials, a member of the Katanino JFM community is anyone living within $5 \mathrm{~km}$ from the edge of the Katanino Local Forest. However, according to local leadership in the area, anyone wishing to join the Katanino Joint Forest Management Area must apply to its executive committee which decides whether or not to accept them based on the applicant's forest use record. The local community is meant to have usufruct rights to access, withdraw and manage the forest through JFM, while the formal ownership of the forest rests with the state (Table 3 ).

The responsibilities of the community include annual forest boundary maintenance; early burning; control of late fires; and forest monitoring. Results from this study reveal that only 12 people contribute towards these community responsibilities. The small bundle of rights for the Katanino JFM community has limited the actions the community is willing to undertake in terms of forest management. They thus do not exercise their rights of management as claimants [26]. Better community participation could be achieved if the collective choice rights of exclusion and withdrawal were to be enforced.

We further contend that the Katanino community members do not assert their right to manage the Katanino Local Forest because they are not dependent on its forest resources. Forest cash income comprises around 3\% of total annual income for Katanino households, and only $13 \%$ of the households that access the Katanino Local Forest sell forest resources from there. Households access the bulk of their forest resources from open areas (forested areas not gazetted as forests) and from their own uncultivated fields. Many households have land that has remained fallow for more than 10 years or has never been cultivated since it came under their ownership.

Table 3. Status of Rights in the Katanino Area

\begin{tabular}{|c|c|}
\hline Right & Right Holder(s) \\
\hline \hline Access & Community and state \\
\hline Withdrawal & Community (NTFP only) \\
\hline Management & Community \\
\hline Exclusion & Community \\
\hline Alienation & State \\
\hline Source: $[26]$. &
\end{tabular}

Using the Framework for Analysing Resource Use Problems, we found that: (i) It is difficult for participating community members to exclude non-members from accessing the forest.

(ii) The regime is characterized by excessive third party control (the FD). There is confusion about what norms, conventions, or rules apply under JFM, e.g. what punishments to mete out for different types of offences. Seventy one percent of the respondents mentioned 13 different entities as being responsible for enforcing sanctions, while $29 \%$ did not know who was responsible.

(iii) There is little interaction among the JFM villages on forest management issues. Distances between villages are quite large, making communication difficult. Another reason is that some households $(40 \%$ of the JFM community) do not utilize the Katanino Local Forest at all and see little reason for participating in its management.

(iv) Many choose not to cooperate in JFM because they perceive no individual benefits in doing so. Almost all the survey respondents and focus group discussants remarked on the extreme reluctance of community members to work for community benefits, when there is no guarantee that other members will do the same. This phobia about 'free riding' is probably a legacy of past failed collective choice arrangements, as "I will never work with them again" was a sentiment frequently echoed. Past experiences with successful organization of projects affect chances of successful collective action [16].

The incentive of entire community benefits from the Katanino Local Forest does not seem sufficient to spur local people's common actions. Rather, individual and immediate household benefits are preferred. We did note, however, that while mistrust was displayed in community projects, where individuals proved reluctant to invest personal time and resources, co-operation was very evident in reciprocal relations, e.g. extended family members helping each other in meeting household labour constraints, sharing food and other filial obligations.

\subsubsection{Collective Choice Arrangements}

The JFM activity is organized by Village Resource Management Committees (VRMCs) at the village level, and with local community representatives in the Forest Management Committee (FMC) at the area level. In practice, local people have little influence because:

The Village Resource Management Committees do not call meetings for local people. In our experience, on the rare occasions when meetings were called, they were arranged for visitors' benefits. Such meetings addressed visitor(s) interests and were often poorly attended by local people. Decisions made seldom represent the 'community'. Generally, only executive committee members of user groups, the patrolmen, and honorary forestry officers attend the meetings. Some $60 \%$ of the respondents had never attended meetings where JFM was discussed, typically due to "lack of interest and tangible benefits". 
(ii) The FMC and VRMCs do not hold executive meetings. These committees are supposed to articulate community interests, but are commonly perceived to be "a small clique of individuals who do not represent the community". When asked why the community did not substitute non-functioning members, there was a perception that office bearers could not be replaced because "the other community members do not have the training necessary to belong to a committee that the current office bearers received under PFAP"2.

(iii) The VRMC and FMC meant to represent the community are unknown to most community members. Eighty-one percent of the respondents have no opinion on the functioning of the VRMCs and $73 \%$ no opinion on the FMC, while the figure for user groups is $68 \%$. The concept that a few individuals should represent the whole community is seen as normatively unacceptable by most community members. All want to be involved in the decision-making processes and speak for themselves. Decisions are not accepted by someone "who was not there in person" [cf. 34].

In principle, all community members may participate in formulating legally binding operational rules specific to their community, through bylaws. Under the JFM legislation, rules and regulations stipulated in the forest management plan acquire legal status upon registration of the management plan by the Ministry of the Environment [30].

In practice, and as revealed during the fieldwork, only a small group of people is heard, usually the local elites present at every meeting, workshop or training session organized for the community. Other community members rarely counter their opinions because the elites are considered to be more knowledgeable. They are often benefactors of poorer community members who would never publicly disagree with them. Local elites within a forest community often capture the bulk of the benefits, quite possibly increasing the misery of the poor [42]. Elite capture, the process by which elites dominate and corrupt community level planning and governance [43], and JFM institutions in Katanino seem to be mutually reinforcing. Low levels of community participation and over-representation of elites on local committees encourage elite capture, while participation by poorer community members in JFM activities is substantially reduced because, to repeat a sentiment echoed several times during interviews: "...we did not get anything. Everything went to the committee so we quit".

In essence, there is no real local representation in the present practices in the study area. One could argue that this reflects local power relations which allow local elites to use the organizational structure to serve their own interests. In Nepal's Terai, the combination of high forest value and inadequate institutional control mechanisms created opportunities for local elites to siphon off considerable shares of the benefits generated by valuable local forests [44].

\footnotetext{
${ }^{2}$ A local leader expressed this view. Most local people do not think the current group of leaders can be replaced, even if they are not effective.
}

When the state transfers resource control into the hands of certain local groups, the rural poor are likely to be differentially affected [45]. In their study of JFM in the state of Andhra Pradesh, Saito-Jensen and Jensen [45] found that JFM was perceived to have negatively affected the ability of the poorest households to derive benefits from the forests due to their higher dependence on forest resources compared to the richer households. The effectiveness of formalized local participation in forest governance via decentralization is debated because of fears that it can lead to resource capture by local elites. Such projects remain ineffectual without extensive devolution of rights to local participants and functional linkages between local decentralized institutions and well-crafted macro level governance institutions $[46,47]$.

\subsection{Physical Status of the Katanino Forest: Proof of Inappropriate Regime Change?}

In view of the regime change, which is premised on the assumption that the Katanino Local Forest is under de facto open access, one would have expected the forest to have been either severely or at least partially deforested. This, however, is not the case. While there was some evidence of pilfering (e.g. trees felled for bark rope, honey, etc.), the forest was generally in good physical condition (Fig. 3). This cannot be attributed to good management by Forestry Department officials because, by their own admission which was confirmed by the Katanino JFM Area community, they hardly visit the area. Local community monitors had been significantly hindered by the inertia of the FMC and VRMCs and by lack of remuneration for their efforts. Their lack of training and unfamiliarity with duties and powers had severely limited their work. Further hindrances were weak local institutions and apathy by the local community.

Our field research suggests that the good physical condition of the Katanino Local Forest could, therefore, be due to:

(i) The local community has alternative sources of forest resources.

(ii) Forest access by outsiders is extremely limited as the forest is surrounded by villages.

(iii) Crop production is much more important as a livelihood strategy than forest use.

(iv) The local community perceives the Katanino Local Forest as a protected forest which they are not allowed to access. When asked why they thought that accessing the Katanino Local Forest was not allowed, more than $50 \%$ of respondents said it is because the forest belongs to the government.

In one way, our case is instructive of a misguided blueprint approach that does not encompass local, social and ecological heterogeneity. The case represents, at least for the time being and with the present resource conditions within the forest, an institutional overkill. There is a misfit between the resource, local resource use, and the institutional regime. The regime change has further not altered the perception of local communities that the forest belongs solely to the state. It seems inappropriate to introduce a regime change based on the general assumption that the previous regime had led to 
forest degradation due to lack of community benefits and community involvement. In our case illustrated here, the forest is actually in a good condition. Furthermore, the new regime does not provide incentives to a community that has easily accessible alternative forest resources which do not necessitate the planning and management responsibilities associated with the new regime.

The rather good condition of the studied forest also reflects a situation of low rivalry in consumption and medium costs of exclusion. Low rivalry is normally not a situation where a rather costly common property regime under the JFM would be the ideal solution. Collective action is more likely to result where the common resource is critical to local incomes and is scarce [48]. This situation is, however, not true for all JFM pilot areas in Zambia. In the Sibuchinga area, where JFM is practiced on customary land, there is very little forest left. An evaluation of the performance of JFM in Dambwa, Livingstone where JFM of a gazetted forest reserve had been implemented found that the forest had been over-exploited prior to JFM and rendered uneconomical for commercial exploitation to provide benefits to local people on a sustainable basis. The Forestry Department was perceived to be the major beneficiary of the JFM, and local elites were more involved in JFM activities than other members of the local community [49]. We argue that it is important to consider different approaches of JFM for forests on state land and those on customary land - again attempting to avoid a 'blueprint' approach.

\subsection{The JFM Implementation Process}

Assessing the impact of an intervention requires a particular focus on the implementation process itself, since timing, proficiency of implementers, resources at hand, and the compatibility of new structures and institutions imposed on existing structures have a crucial effect on outcomes. The 'set-in-stone' JFM implementation resulted in inappropriate approaches in many local settings. With the completion of the pilot JFM phase, even the most promising community projects collapsed and committees and user groups stopped functioning [34]. Our respondents pointed to incentives used for JFM participation during the pilot phase such as food in meetings, training, and remuneration for helping the Forestry Department with boundary maintenance. Some got bicycles and all were promised money once the issuing of permits for forest products by the community was underway. In the postpilot phase, the community was expected to contribute free labour to look after 'their' forest. However, local people contended that "since the foresters were remunerated for forest management activities when the forest belonged to Forestry Department, it would only be fair that the community now got the same". This view emerged in all group interviews and focus group discussions and was unanimous. Without tangible, immediate, individual or household benefits, the community members did not seem prepared to become involved in JFM activities.

This reluctance was also evident in the non-performance of the local organizations set up for JFM. Only $8 \%$ of respondents reported that the VRMCs work well, while the rest said that the committees do nothing. Only $9 \%$ said that the FMC is effective (mostly executive members), while $14.7 \%$ (mostly former executive members) said the committee is dead and was only 'resurrected' by the presence of visitors. Ordinary community members are ignorant of JFM rules and regulations. Almost $70 \%$ do not know who manages the forest, who makes the rules for forest management, or who punishes forest offenders. An overwhelming majority have never attended a village meeting where JFM was discussed. These examples question not only the suitability of the present JFM structure in the area, but also the implementation proficiency. In a nutshell, the regime change has been inappropriate for the Katanino JFM Area community.

\section{CONCLUSIONS}

This study from Zambia has demonstrated important challenges of JFM. Findings indicate inappropriate blueprint approaches in JFM policy design and implementation, constraining the ability to address local heterogeneity of both resource characteristics and local communities. The formal rules set by government are inflexible and insensitive to heterogeneous local settings. Monitoring mechanisms have collapsed, reportedly due to a lack of remuneration for the local monitors. There are no effective mechanisms for incorporating lessons learnt, and conflicts remain unresolved for long periods. Systems for sanctions are unclear and mostly unknown, with no evidence of punishment for forest offenders having been imposed.

The state's attempt to enable the Katanino Joint Forest Management Area to be managed under a common property regime, by conferring access and use rights, has thus been fraught with challenges, and the costs to the local community do not seem to be justified by the purported benefits. This is particularly true in this case because most benefits are accessible elsewhere without the associated JFM costs. JFM aims in general to remove 'open access' situations assumed to exist in state-run forests, by identifying 'local communities' as co-owners and excluding outsiders from forest use, while managing the resource sustainably. The resource regime introduced under JFM was intended to change the de facto open access situation presumed to exist under sole state management, to a common property regime. However, it seems inappropriate to introduce a resource regime premised on successful collective choice arrangements into a community where the members do not see themselves as being organized for communal benefits; and where little effort is expended in building collective choice structures. The strengths of involving the local community in natural resource management are not evident in this situation.

A stronger emphasis is recommended on designing a JFM policy involving local people, local institutions, and local organizations from the start. Social heterogeneity, local politics and power relations should be considered. One may also consider the degree of devolution, from co-management to more comprehensive transfer of power and total ownership of local forests to the communities, as alternatives to the present JFM regime. A conscious focus on competent implementation implies more economic, technical and social skills training and support for forest extension officers, local authorities and local institutions at large. As much as policy design, implementation itself can be decisive for the success or failure of devolving authority, powers and resource access 
in the slow processes of social change that such policies in their various forms imply.

\section{CONFLICT OF INTEREST}

The authors confirm that this article content has no conflicts of interest.

\section{ACKNOWLEDGEMENTS}

We would like to thank Professor Arild Vatn, NORAGRIC, for useful comments on draft versions of this paper, and NORAD, Ministry of Foreign Affairs for supporting a fellowship for the research.

\section{REFERENCES}

[1] Adams W, Hulme D. Conservation and Community. In: Hulme D, Marshall M., Eds. African Wildlife and Livelihoods. Oxford: James Currey Limited 2001.

[2] Hutton J, Adams WM, Murombedzi JC. Back to the Barriers? Changing Narratives in Biodiversity Conservation. Forum Dev Stud 2005; 32: 341-65.

[3] Gibson C. Politicians and Poachers. The Political Economy of Wildlife Policy in Africa. Cambridge: Cambridge University Press 1999.

[4] Government of the Republic of Zambia. National Energy Policy. Department of Energy, Lusaka: Ministry of Energy and Water Development 2008.

[5] Government of the Republic of Zambia. Joint Forest Management Guidelines. In: Forestry Department, Lusaka: Forestry Department/ MTENR 2005.

[6] Puustjärvi E, Kokwe GM, Chakanga M. The contribution of the forest sector to the national economy and poverty reduction in Zambia. Lusaka: Savcor Indufor 2005.

[7] Government of the Republic of Zambia. Integrated Land Use Assessment (ILUA) 2005-2008. In: Forestry Department, Lusaka: MTENR 2010.

[8] Hardin G. The tragedy of the commons. Science 1968; 162: 12438 .

[9] Behera B, Engel S. Institutional Analysis of Evolution of Joint Forest Management (JFM) in India: A New Institutional Economics (NIE) Approach. For Policy Econ 2006; 8: 350-62.

[10] Agrawal A, Gibson C. Enchantment and Disenchantment: The role of community in natural resource conservation. World Dev 1999; 27: 629-49.

[11] Kumar S, Kant S. Bureaucracy and new management paradigms: modeling foresters' perceptions regarding community-based forest management in India. For Policy Econ 2005; 7: 651-69.

[12] Agrawal A, Ostrom E. Collective action, property rights, and devolution of forest and protected area management 1999. Available from: http.//www.capri.cgiar.org [cited: 2010 Sept 10th].

[13] Zulu LC. Community forest management in southern Malawi: solution or part of the problem? Soc Nat Resour 2008; 21: 687-703.

[14] Meynen W, Doornbos M. Decetralizing Natural Resource Management: A Recipe for Sustainability and Equity? In: Ribot JC, Larson, AM. Eds. Democratic Decentralization through a Natural Resource Lens. New York: Routledge 2005; pp. 235-60.

[15] Pretty J. Regenerating Agriculture. Policies and Practices for Sustainability and Self-reliance. London: Earthscan 1995.

[16] Ostrom E. Self Governance and Forest Resources. Local Institutions for Forest Management1997; Bogor, Indonesia, 1997: IFRI/CIFOR Workshop.

[17] Zhang M, Wang S. Co-management: transformation of community affair model in Chinese nature reserves. J Forestry Res 2004; 15: 313-8.

[18] Ostrom E. Governing the Commons. New York: Cambridge University Press 1990.

[19] Ostrom E. How Types of Goods and Property Rights Jointly Affect Collective Action. J Theor Polit 2003; 15: 239-70.

[20] Paavola J. Institutions and Environmental Governance: a reconceptualization. Ecol Econ 2007; 63: 93-103.

[21] Berkes FP, Nayak K. Politics of Co-Optation: Community Forest Management versus Joint Forest Management in Orissa, India. Environ Manage 2008; 41: 707-18.

[22] Ostrom V, John R. Common's Foundations for Policy Analysis. J Econ Issues 1976; 10: 839-57.

[23] Ostrom E. An Agenda for the Study of Institutions. Public Choice 1986; 48: 3-25.

[24] Commons JR. Legal Foundations of Capitalism. Madison: University of Wisconsin Press 1968.

[25] Ostrom E. Private and Common Property-Rights. Center for the Study of Institutions, Population, and Environmental Change. Indiana University 2000.

[26] Schlager E, Ostrom E. Property-rights regimes and natural resources: a conceptual analysis. Land Econ 1992; 68: 249-62.

[27] Vatn A. Resource regimes and cooperation. Land Use Policy 2007; 24: 624-32.

[28] The Local Forests (Control and Management) Regulations. SI/52, 1998.

[29] Government of the Republic of Zambia. Forests Act (c.7) of 1999. Lusaka. Government Printers 1999.

[30] Programme Coordination Unit. Provincial Forestry Action Programme. Lessons Learnt from Joint Forest Management in Zambia. The Experiences of PFAP II. Lusaka: PCU/Forestry Department 2005a.

[31]. Gibbon H, Mbithi D, Mugo EN, et al. Forest and woodland management in East and Central Africa: Emerging models for improvement in livelihoods and natural resource management in Kenya and Zambia. Int Forest Rev 2005; 7: 193-207.

[32] Arnold JEM. 25 Years of Community Forestry. Rome: Food and Agricultural Organization of the United Nations 2001.

[33] Jere P. Legal Aspects of Joint Forest Management in Zambia. Lusaka: Forestry Department 2004.

[34] Programme Coordination Unit. Programme Completion Report 2000-2005. Lusaka: PCU/Forestry Department 2005b.

[35] Bwalya, B. Joint Forest Management in Katanino Forest Area, Masaiti, Zambia: Challenges and Opportunities. Msc Thesis. Aas. Department of International Environment and Development Studies. Norwegian University of Life Sciences 2007.

[36] Forestry Department. Participatory Forest Management Plan: Katanino JFMA. Masaiti. Lusaka: Forestry Department 2003.

[37] Central Statistical Office. Zambia 2000 Census of Population and Housing. Housing and Household Characteristics Analytical Report. In: Ministry of Finance and National Planning. Lusaka: Government of the Republic of Zambia 2003.

[38] Minitab Inc. Minitab 14 Statistical Software. State College: Minitab Inc 2006.

[39] Nielsen MR. Improving the conservation status of the udzungwa mountain, tanzania? the effect of joint forest management on bushmeat hunting in the Kilombero nature reserve. Conserv Soc 2011; 9: 106-18.

[40] Puustjärvi E, Kokwe GM, Chakanga M. The contribution of the Forest Sector to the National Economy and Poverty Reduction in Zambia. Consultancy Report to Indufor Oy for the Zambian Forestry Department and Ministry for Foreign Affairs of Finland. Helsinki: Savcor Indufor Oy 2005.

[41] Vedeld P, Angelsen A, Sjaastad E, et al. Counting on the Environment: Forest Incomes and the Rural Poor. Washington, D.C: The World Bank 2004.

[42] Datta S, Charkravarti MH, Nugent J. Joint Forest Management: Experience and Modelling. Ahmedabad: Indian Institute of Management 2004.

[43] Dasgupta A, Beard VA. Community Driven Development, Collective Action and Elite Capture in Indonesia. Dev Change 2007; 38: 229-49.

[44] Iversen V, Chhetry B, Francis P, et al. High value forests, hidden economies and elite capture: Evidence from forest user groups in Nepal's Terai. Ecol Econ 2006; 58: 93-107.

[45] Saito-Jensen M, Jensen CB. Rearranging Social Space: BoundaryMaking and Boundary-Work in a Joint Forest Management Project, Andhra Pradesh, India. Conserv Soc 2010; 8: 196-208. 
[46] Andersson KP, Gibson CC, Lehoucq F. Municipal politics and Forest Governance: Comparative analysis of decentralization in Bolivia and Guatemala. World Dev 2006; 34: 576-95.

[47] Persha L, Agrawal A, Chhatre A. Social and Ecological Synergy: Local Rulemaking, Forest Livelihoods, and Biodiversity Conservation. Science 2011; 331: 1606-8.
[48] Baland JM, Platteau JB. Halting Degradation of Natural Resources. Is there a role for rural communities? Oxford: Clarendon Press 1996.

[49] Phiri M. Evaluation of the Performance of Joint Forest Management (JFM) Programme: Case of Dambwa Forest Reserve in Livingstone District, Zambia. Stellenbosch: Stellenbosch University 2009.

(C) Umar and Vedeld; Licensee Bentham Open.

This is an open access article licensed under the terms of the Creative Commons Attribution Non-Commercial License (http://creativecommons.org/licenses/by$\mathrm{nc} / 3.0 /$ ) which permits unrestricted, non-commercial use, distribution and reproduction in any medium, provided the work is properly cited. 